\title{
Stoichiometry of carbon, nitrogen and phosphorus in wastewater from Romania
}

\author{
FLORINELA PIRVU $^{1,2}$, IULIANA PAUN ${ }^{1}$, MARCELA NICULESCU ${ }^{1}$, IANCU VASILE ION ${ }^{1}$, \\ LUOANA FLORENTINA PASCU ${ }^{1}$, FLORENTINA LAURA CHIRIAC ${ }^{1 *}$
}

\begin{abstract}
${ }^{1}$ National Research and Development Institute for Industrial Ecology ECOIND, 71-73 Drumul Podu Dambovitei Street, district 6, 060652, Bucharest, Romania

${ }^{2}$ University Politehnica of Bucharest, 313 Splaiul Independentei Street, district 6, code 060042 Bucharest, Romania

*Corresponding author: laura.chiriac@incdecoind.ro
\end{abstract}

$\begin{array}{lll}\text { Received: } & \text { Accepted: } & \text { Published: } \\ \text { 16.11.2021 } & 10.12 .2021 & 17.12 .2021\end{array}$

\begin{abstract}
Water resources crisis can lead to a new concept of wastewater treatment. Wastewater cannot be considered waste, but can be a renewable or non-renewable energy source. Nutrients from wastewater could be recycled and not disposed of. A circular economy can be created that can be based on the ability of algae to absorb and store nutrients: carbon $(C)$, nitrogen $(N)$ and phosphorus $(P)$.

This study investigates the stoichiometry between carbon, nitrogen and phosphorus in wastewater from three geographical regions of Romania. The concentrations of inorganic nitrogen, total nitrogen, total phosphorus and total organic carbon were compared and evaluated. Three wastewater sampling points located in different areas were monitored, in the period 2013-2017 for the sampling point located in the central-northern part of the Romanian Plain and in the period 2015-2017 for the other two studied areas. The obtained results showed very high values of total nitrogen concentrations with values between $28.2 \mathrm{mg} / \mathrm{L}$ and $107.2 \mathrm{mg} / \mathrm{L}$ for the southeastern part of Romania. The values of the stoichiometric ratio's $C / N, C / P, N / P$ have varied over time with maximums in the autumn and winter seasons which indicates the existence of significant contamination of wastewater. It may be possible in the future to improve the performance of wastewater treatment by adjusting $C, N$ and $P$ parameters.
\end{abstract}

Keywords: wastewater, inorganic nitrogen, total phosphorus, total organic carbon, stoichiometry

\section{INTRODUCTION}

In recent decades, conventional wastewater treatment processes focused to remove carbon (C), nitrogen $(\mathrm{N})$ and phosphorus $(\mathrm{P})$ have contributed to environmental protection. During the wastewater treatment process, the discharge of waste sludge and the emission of greenhouse gases $\left(\mathrm{CO}_{2}\right.$ and $\left.\mathrm{N}_{2} \mathrm{O}\right)$ can be a challenge for wastewater management. To create a circular economy, waste could be turned into reusable resources instead of disposing them [1,2].

Municipal wastewater treatment plants are necessary for environmental protection but may require a consumption of about 3\% of electricity and about 5\% of greenhouse gas emissions [3]. The presence of pollutants in the wastewater reaching the Wastewater Treatment Plant (WWTP), in quantities exceeding the maximum allowed limits, either due to the fact that the waters discharged by a series of economic agents are heavily loaded with organic and inorganic pollutants, or due to the sum of pollutants content from various activities in sewerage, can lead to increased operating costs of equipment and installations [4]. The wastewater entering the WWTP is composed in different proportions of domestic or industrial wastewater; rainwater-weather; imported water comes from springs, underground infiltrations, basements, drainage ditches. The composition of wastewater at the entrance to the station is given by the different composition of these types of 
water: wastewater is polluted mainly with organic compounds and contains various microorganisms (bacteria, viruses, parasites) [5]; rainwater contains mainly inorganic and mineral compounds; imported waters have a varied content depending on their origin [6]. Depending on the nature of the use and the technological process, the wastewater carries smaller or larger quantities of liquid or solid pollutants, from raw materials or intermediate and finished products from manufacturing processes [7]. Wastewater contains, in dissolved form, in colloidal dispersion and in suspension, a large variety of organic and mineral substances, natural and synthetic products resulting from the production activity as well as microorganisms [8]. The materials that are in a state of colloidal dispersion and in suspension are often made of clay, dust and fine sand, entrained in rainwater sewerage as well as those resulting from the conditioning of raw materials. Organic substances are represented by practically all the components of the three main categories: carbohydrates, proteins and lipids, as well as by their products of metabolism and biochemical decomposition [9]. Among carbohydrates, polysaccharides in the form of cellulose, starch or simpler compounds, such as hexoses, pentoses, etc., are dominated in wastewater, resulting from industrial activities characterized by large volumes of wastewater discharged: pulp and paper industry, wood industry, textile industry, food industry [10]. They are found in large quantities in domestic waters, due to the share of plant products in the diet. Along with these main groups of substances, in the wastewater are also found their decomposition products, represented mainly by: phenols, amines, urea, ammonia, hydrogen sulfide. The decomposition processes are due to the activity of bacterial microflora found in the human and animal digestive tract or bacterial microflora that grows in sewage systems, wastewater also contains, in large quantities, microorganisms that use the nutrient substrate of these waters [11]. To the mentioned natural organic substances, which are part of the biological cycle, are added fossil natural organic substances, such as those from the oil and coal industry, as well as synthetic organic substances made from these products: detergents, plastics, phytopharmaceuticals, drugs and synthetic dyes [12]. Synthetic organic pollutants are characteristic of wastewater from the petrochemical industry, synthetic organic chemistry and light industry. The modifications of the physical-chemical characteristics of the emissary waters, in the discharge areas, start with the physical properties: color, transparency, smell, temperature, the amount of suspended matter, which modifies according to the respective physical characteristics of the wastewater. These changes are also the first signs of the presence of pollutants in the waters of a river, recorded by the sense organs. Nutrients: carbon $(\mathrm{C})$, nitrogen $(\mathrm{N})$ and phosphorus $(\mathrm{P})$ are removed during water treatment.

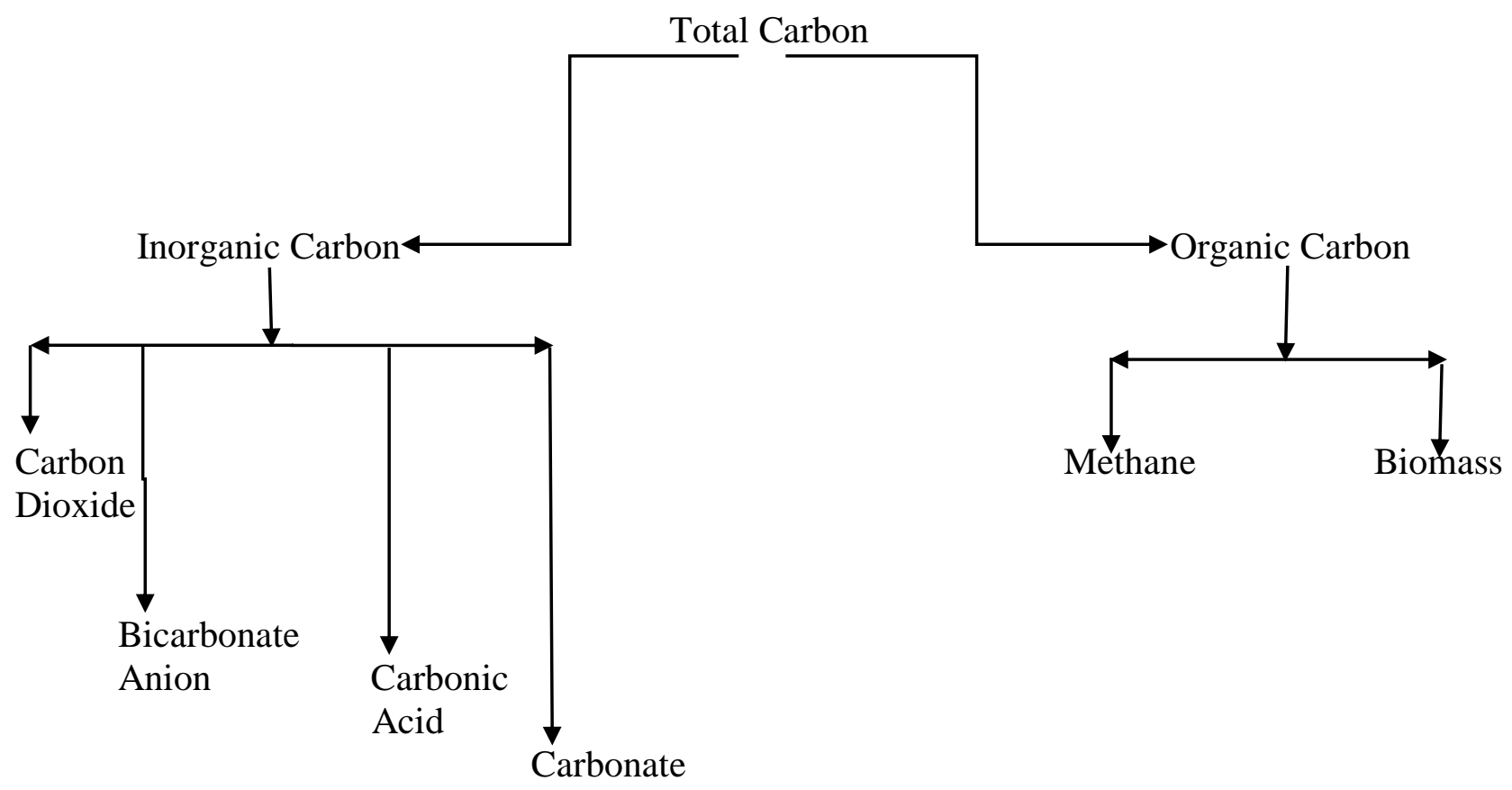

Fig. 1. Carbon removal mechanisms from wastewater 
Total carbon represents the carbon amount obtained after inorganic and organic fraction transformation (Figure 1). Organic carbon can be composed mainly of methane and biomass, while inorganic carbon can be generated mainly by inorganic compounds such as carbonates, carbonic acid, bicarbonate anion and carbon dioxide $[13,14]$.

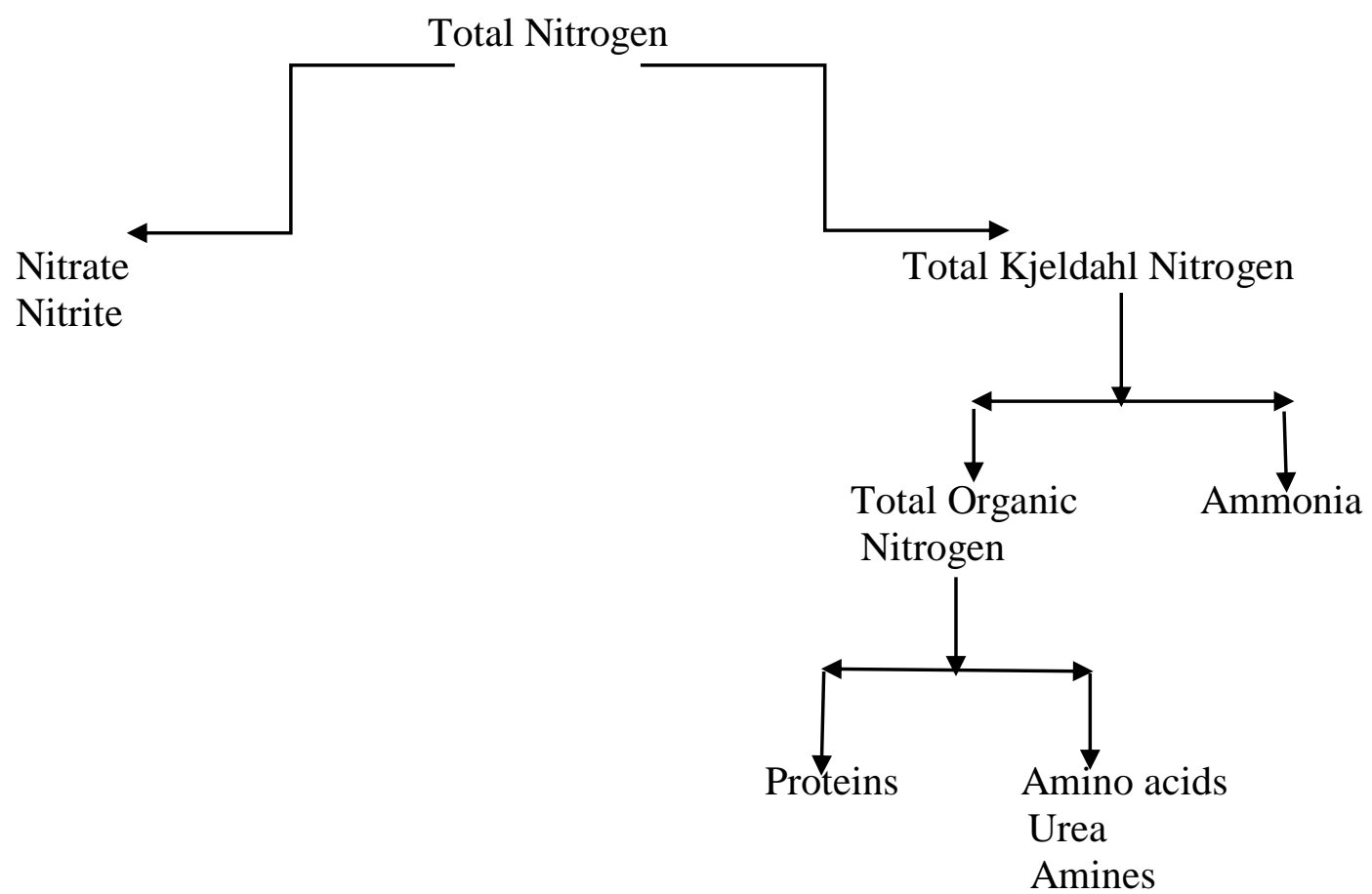

Fig. 2. Nitrogen removal mechanisms from wastewater

Mechanisms of nitrogen removal by aerobic technology such as nitrification and denitrification together with ammonium oxidation they can have an efficiency of approximately 78\% [15-17], in the case of ammonia nitrogen. Regarding the total organic nitrogen, an amount of approximately 8.2 $\mathrm{mg} / \mathrm{L}$ has been reported in the wastewater effluent [18] demonstrating that it cannot be completely removed. Phosphorus removal mechanism in WWTPs are presented in Figure 2.

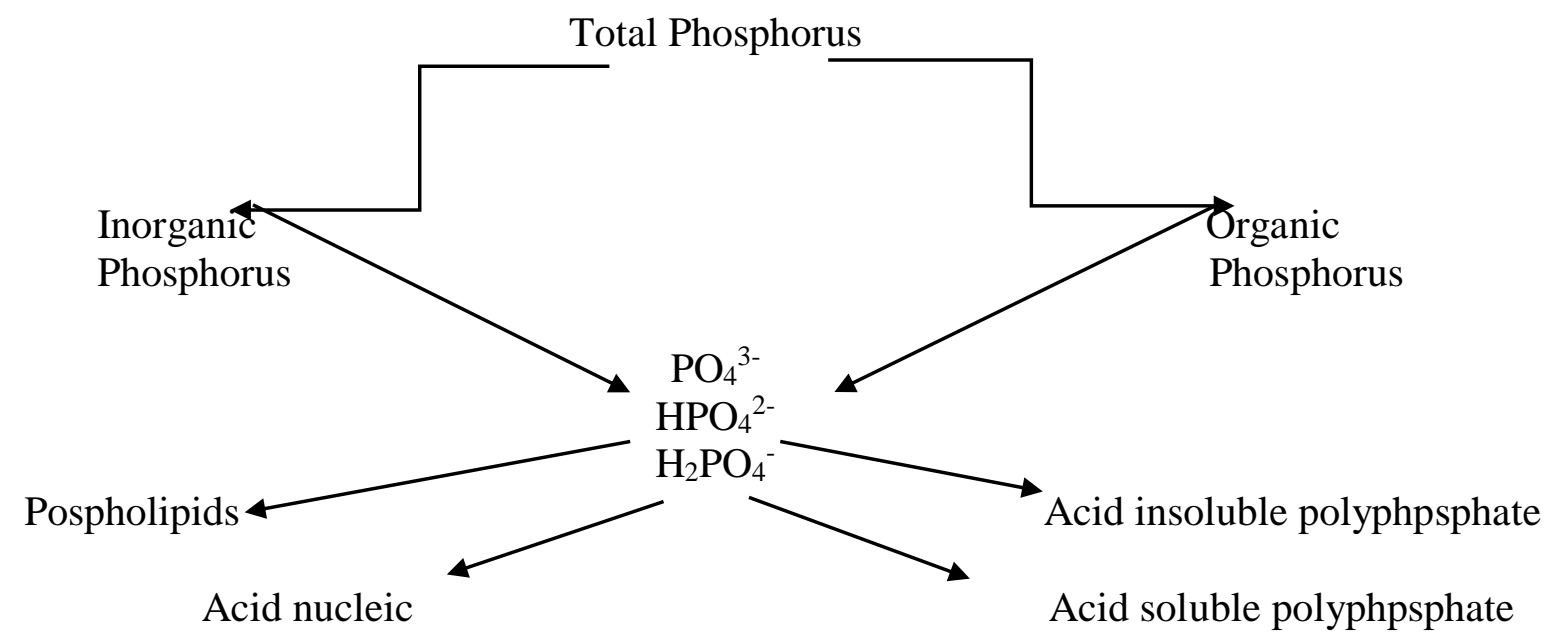

Fig. 3. Phosphorus removal mechanisms from wastewater

Phosphorus is a fundamental macronutrient for algae because with its help, algae synthesize nucleic acids. Among the inorganic phosphates present in Figure 3, depending on the $\mathrm{pH}$, those with a lower load are more bioavailable than those whose load is higher, and this bioavailability may also depend on the alkalinity or acidity of the cell membrane [19-21]. Acid-soluble polyphosphates are synthesized in the presence of light. During the process of photosynthesis, they can produce 
proteins. Acid-insoluble polyphosphates are used to support algae viability [22, 23]. In the environment, the level of phosphorus can be influenced by its cellular metabolism, and its elimination is related to its nutritional character. Light intensity may allow microalgae to have a content 4 times the normal metabolism required [24] and when using diurnal cycles for the treatment of microalgae-based wastewater, the phosphate concentration could be taken into account [25].

The aim of the study was to process and evaluate elements such as carbon $(\mathrm{C})$, nitrogen $(\mathrm{N})$ and phosphorus $(\mathrm{P})$ which due to population growth, industrialization of agriculture and excessive application of nitrogen fertilizers have affected the loading of wastewater with these elements. Stoichiometry can be used on an ecosystem scale to provide information on how nutrients $\mathrm{C}, \mathrm{N}$ and $\mathrm{P}$ enter, are retained and can be removed from the ecosystem. Samples were taken from 3 different areas of Romania for a period of 5 years (2013-2017) for the northern central area of the Romanian Plain and for the central area of Romania and the southeastern area of Romania the samples were taken in the period (2015-2017). Stoichiometric ratios for nutrients were calculated: carbon, nitrogen and phosphorus, namely: $\mathrm{C} / \mathrm{N}, \mathrm{C} / \mathrm{P}, \mathrm{N} / \mathrm{P}$ and variations in concentrations obtained for inorganic nitrogen, total nitrogen, total phosphorus and total organic carbon were evaluated.

\section{MATERIALS AND METHODS}

\section{The study area}

Wastewater sampling and chemical analysis was performed from 3 wastewater collection points located in 3 different areas of Romania. The first area (S1) is located in the northern-central part of the Romanian Plain with an average annual temperature of $10^{\circ} \mathrm{C}$, and average annual rainfall of 600 $\mathrm{mm}$, the second area (S2) is located in the northeast part of Arges County with an average annual temperature of $9{ }^{\circ} \mathrm{C}$, and the average annual rainfall ranges between $700-800 \mathrm{~mm}$. The third studied area (S3) is located in the north of Bucharest, with an average annual temperature of $17^{0} \mathrm{C}$, and rainfall has an annual average of $500 \mathrm{~mm}$.

\section{Wastewater sampling and chemical analysis}

For chemical analysis, the nitrites, nitrates, ammonium, total phosphorus, total nitrogen, total organic carbon parameters were monitored monthly, in the period 2013-2017 for S1 and S2, and between 2015 and 2017, for S3. All selected sources were geographically located using a GPS (GARMIN Model Montana 610 navigation system, GPS / GLONASS navigator). Wastewater samples were collected and transported in glass containers and stored at $4^{\circ} \mathrm{C}$ until appropriate analysis.

Purification and disposal of wastewater directly in the natural environment is carried out according to the Norm on establishing the loading limits with pollutants of industrial and urban wastewater for discharge into natural receptors, according to HG 352/2005 [26].

The indicators to be analyzed, the unit of measurement, the maximum allowed limits and the specific standards for the wastewater samples are presented in Table 1.

Table 1. Normative regarding the establishment of the loading limits with pollutants of industrial and urban wastewater for discharge in natural receptors [26]

\begin{tabular}{l|cclc}
\hline \multicolumn{1}{c|}{ Parameter } & \multicolumn{1}{c}{ Unit } & $\begin{array}{c}\text { Maximum } \\
\text { Limit }\end{array}$ & \multicolumn{1}{c}{ Method } & References \\
\hline Ammonia nitrogen & $\mathrm{mgNH}_{4}{ }^{+} / \mathrm{L}$ & $2(3)$ & SR ISO 7150-1:01 & {$[27]$} \\
$\left(\mathrm{NH}_{4}-\mathrm{N}\right)$ & $\mathrm{mgN} / \mathrm{L}^{-}$ & $10(15)$ & SR EN 12260:04 & {$[28]$} \\
Total nitrogen $(\mathrm{TN})$ & $\mathrm{mgNO}_{3}-\mathrm{L}$ & $25(37)$ & SR ISO 7890-3:00 & {$[29]$} \\
Nitrates $\left(\mathrm{NO}_{2}-\mathrm{N}\right)$ & $\mathrm{mgNO}_{2}{ }^{-} / \mathrm{L}$ & $1(2)$ & SR EN 26777:02 & SR EN 26777:02/C91:06 \\
Nitrites $\left(\mathrm{NO}_{3}-\mathrm{N}\right)$ & $\mathrm{mg} / \mathrm{L}$ & $1(2)$ & SR EN ISO 6878:05, pct 4.8 & {$[31]$} \\
Total phosphorus $(\mathrm{TP})$ & & & & \\
\hline
\end{tabular}




\section{RESULTS AND DISCUSSION}

To examine the stoichiometry of wastewater from the 3 areas studied, their loading with N, P and C was evaluated. In the case of nitrogen, depending on the chemical analysis performed, inorganic nitrogen or total nitrogen was evaluated. For phosphorus parameter, total phosphorus (inorganic and organic phosphorus) was analyzed, while for carbon, the contributions of total organic carbon to the experimental data were evaluated.

Table 2. Stoichiometric estimates of inorganic nitrogen, total phosphorus, and total organic carbon from wastewater samples collected from S1 sampling point during 2013-2017

\begin{tabular}{c|cccccccccccc}
\hline Month & Jan & Feb & Mar & Apr & May & Jun & Jul & Aug & Sep & Oct & Nov & Dec \\
& & & & & & & & & & & & \\
\hline C/N/2013 & 0.21 & 0.22 & 0.05 & 0.08 & 0.07 & 0.06 & 0.19 & - & 0.21 & 0.09 & 0.23 & 0.62 \\
C/P/2013 & 5.25 & 7.29 & 3.69 & 2.83 & 3.73 & 3.73 & 8.59 & - & 8.25 & 6.16 & 6.57 & 13.5 \\
N/P/2013 & 24.6 & 32.7 & 74.6 & 36.0 & 55.0 & 67.8 & 45.6 & - & 39.8 & 68.3 & 28.9 & 21.6 \\
C/N/2014 & 0.08 & 0.14 & 0.26 & 0.17 & 0.12 & 0.10 & 0.17 & 0.19 & 0.01 & 0.06 & 0.18 & 0.19 \\
C/P/2014 & 4.31 & 14.1 & 3.81 & 2.01 & 1.63 & 1.73 & 4.03 & 5.41 & 0.21 & 1.88 & 11.6 & 11.9 \\
N/P/2014 & 53.0 & 100.1 & 14.6 & 11.7 & 13.5 & 18.0 & 23.3 & 27.8 & 34.0 & 29.8 & 64.7 & 64.4 \\
C/N/2015 & 0.35 & 0.21 & - & 0.34 & 0.59 & 0.11 & 0.14 & 0.20 & 0.16 & 0.21 & 0.05 & 0.16 \\
C/P/2015 & 9.39 & 12.7 & 0.02 & 3.87 & 6.40 & 1.17 & 2.16 & 1.36 & 2.83 & 4.60 & 1.10 & 1.51 \\
N/P/2015 & 26.8 & 61.6 & 19.3 & 11.2 & 10.8 & 10.3 & 15.1 & 6.69 & 17.6 & 22.2 & 20.9 & 6.38 \\
C/N/2016 & 0.31 & 0.08 & 0.12 & 0.12 & - & 0.18 & - & 0.08 & 0.01 & 0.37 & 0.02 & 0.13 \\
C/P/2016 & 2.69 & 1.26 & 1.32 & 3.74 & 0.33 & 2.27 & 0.79 & 6.15 & 0.55 & 4.29 & 0.21 & 2.49 \\
N/P/2016 & 8.53 & 16.7 & 11.2 & 30.5 & 22.9 & 12.4 & 80.3 & 76.6 & 48.2 & 11.6 & 14.0 & 18.5 \\
C/N/2017 & 0.13 & 0.09 & 0.17 & 0.02 & 0.01 & 0.05 & 0.20 & 0.15 & 0.52 & 0.08 & 0.10 & 0.11 \\
C/P/2017 & 3.56 & 2.99 & 1.56 & 0.33 & 0.25 & 1.43 & 11.2 & 1.70 & 9.60 & 2.92 & 1.30 & 1.24 \\
N/P/2017 & 26.6 & 31.9 & 9.26 & 20.7 & 17.6 & 30.3 & 57.5 & 11.6 & 18.5 & 37.1 & 13.4 & 11.3 \\
\hline
\end{tabular}

The radio values obtained for $\mathrm{C} / \mathrm{N}, \mathrm{C} / \mathrm{P}, \mathrm{N} / \mathrm{P}$ in wastewater samples are given in Table 2 . Comparing the ratio values, it can be easily seen that $\mathrm{C} / \mathrm{N}$ are subunits, while for $\mathrm{C} / \mathrm{P}$ and $\mathrm{N} / \mathrm{P}$ the values are super unitary. The subunit values of $\mathrm{C} / \mathrm{N}$ means that inorganic and organic compounds with nitrogen are higher than those with carbon. Similarly, given the ratio values between C/P and N/P suggest that the amount of inorganic and organic compounds with phosphorus are lower than those with organic carbon and nitrogen in the wastewater samples.

The $\mathrm{C} / \mathrm{N}$ ratio varied thus, the minimum value was obtained in 2017 (0.01), and the maximum value was identified in $2016(6.15)$. The results of the minimums of the $\mathrm{C}: \mathrm{N}$ ratio were obtained in the order: $\mathrm{C} / \mathrm{N} \_2017<\mathrm{C} / \mathrm{N} \_2016<\mathrm{C} / \mathrm{N} \_2013<\mathrm{C} / \mathrm{N} \_2014<\mathrm{C} / \mathrm{N} \_2015$, and the results of the maximums of the $\mathrm{C} / \mathrm{N}$ ratio had the following variation: $\mathrm{C} / \mathrm{N} \_2016>\mathrm{C} / \mathrm{N} \_2013>\mathrm{C} / \mathrm{N} \_2015>$ C/N_2017 > C/N_2014. The results of the evaluated N/P and C/P ratios had maximum values in winter season when N/P had a value of 100.1, and C/P had a maximum value of 14.1.

The variations of the concentration's values obtained in the study period were closely related to the values of the obtained reports (Figure 4).

Unlike the years 2014 and 2015 in which the maximum values of the concentrations of the evaluated parameters were registered in the autumn season, the maximum values of the concentrations of inorganic nitrogen, total phosphorus and total organic carbon for the years 2013, 2016, 2017 were registered as follows: $82.58 \mathrm{mgN} / \mathrm{L}$ for inorganic nitrogen in 2017, $5.18 \mathrm{mgP} / \mathrm{L}$ for total phosphorus in 2016 and $18.24 \mathrm{mgC} / \mathrm{L}$ for total organic carbon in 2013. 

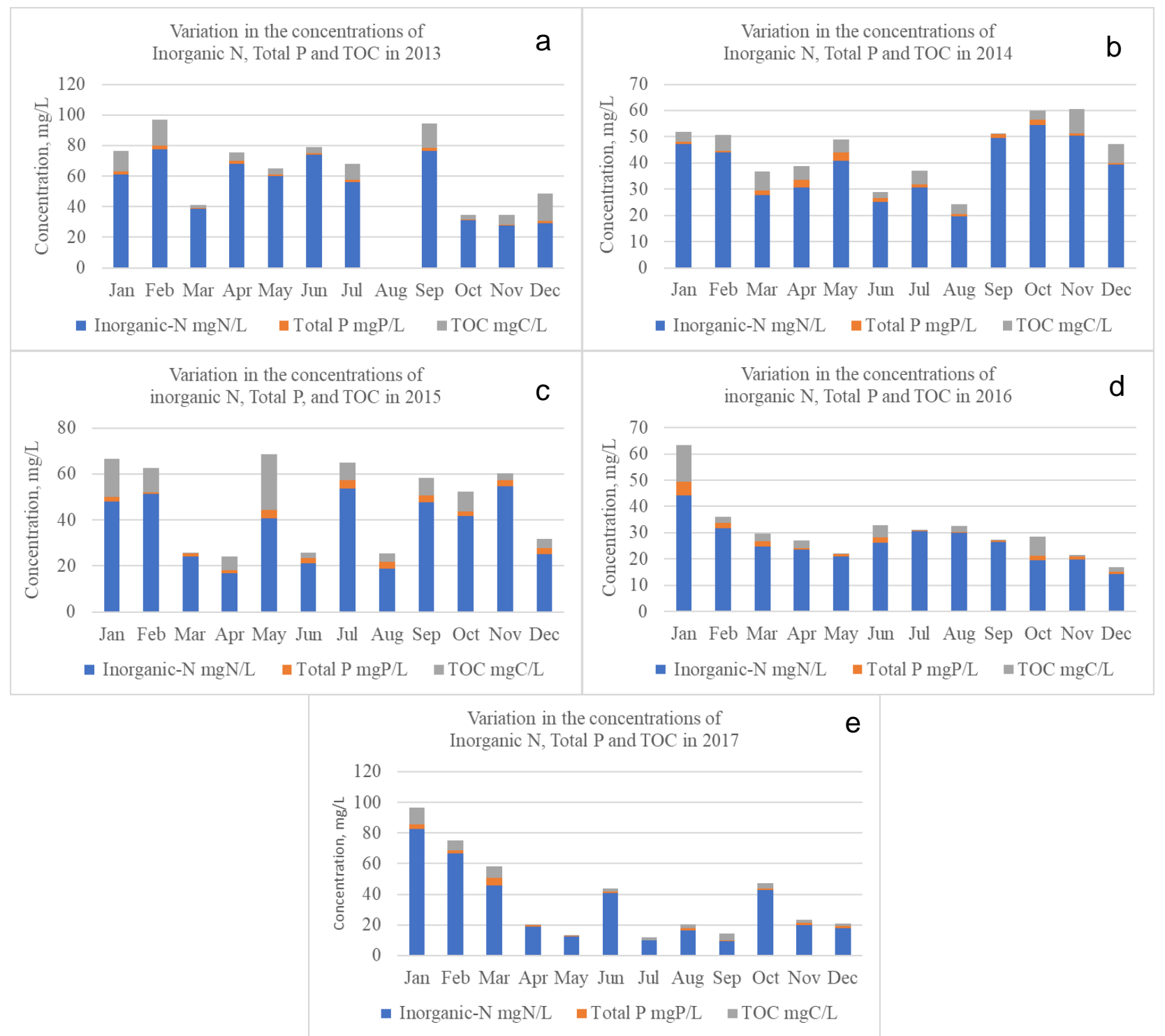

Fig. 4. Concentrations of inorganic nitrogen, total phosphorus and total organic carbon for the samples taken from S1 sampling point: (a) 2013, (b) 2014, (c) 2015, (d) 2016, (e) 2017

Table 3. Stoichiometric estimates of inorganic nitrogen, total phosphorus and total organic carbon from wastewater samples collected from S2 sampling point during 2013-2015

\begin{tabular}{c|cccccccccccc} 
Month & Jan & Feb & Mar & Apr & May & Jun & Jul & Aug & Sep & Oct & Nov & Dec \\
\hline C/N/2013 & 0.01 & 0.01 & 0.01 & - & 0.1 & - & - & - & 0.01 & 0.01 & - & - \\
C/P/2013 & 1.15 & 1.88 & 0.36 & 0.42 & 3.83 & - & 0.63 & - & 0.73 & 0.88 & 0.94 & 0.64 \\
N/P/2013 & 135 & 238 & 35.6 & 160 & 453 & - & 276 & - & 112 & 106 & 250 & 161 \\
C/N/2014 & 0.01 & 0.01 & - & 0.01 & 0.01 & 0.01 & 0.03 & 0.01 & - & 0.02 & 0.05 & 0.01 \\
C/P/2014 & 0.61 & 0.24 & 0.28 & 0.42 & 0.32 & 2.45 & 0.77 & 0.50 & 0.59 & 0.58 & 2.55 & 1.39 \\
N/P/2014 & 110 & 44 & 124 & 50.0 & 31.0 & 252 & 24 & 46 & 125 & 31 & 55 & 197 \\
C/N/2015 & 0.02 & 0.01 & 0.02 & 0.04 & 0.01 & 0.03 & 0.02 & - & 0.01 & - & - & 0.01 \\
C/P/2015 & 0.44 & 0.97 & 0.94 & 1.60 & 0.25 & 0.25 & 1 & 0.10 & 0.16 & 0.29 & 0.25 & 0.45 \\
N/P/2015 & 24.12 & 88.5 & 49.6 & 37.1 & 30 & 10.0 & 49.6 & 19.3 & 30.7 & 81.5 & 63.5 & 58.12 \\
\hline
\end{tabular}

In Table 3 the values of the stoichiometric ratios have the following values: minimum values $\mathrm{C} / \mathrm{N}$ in 2013, 0.01 in January-July 2013 and 2014, maximum values in November 2014, 0.05. For the C/P ratio, minimum values were registered in August 2015, 0.10, and maximum values in 2013, 3.83. Regarding the N/P ratio, the maximum values were recorded in May 2013, 453 and the minimum values in June 2015, 10. 
The values of the $\mathrm{C} / \mathrm{N}$ ratios presented in the table are subunit, which shows that a higher amount of nitrogen-containing compounds is present in the samples compared to carbon-containing organic compounds. Regarding the $\mathrm{C} / \mathrm{P}$ and $\mathrm{N} / \mathrm{P}$ ratio values, a higher number of phosphorus compounds are present in the wastewater samples compared to the number of compounds with carbon, but lower amount of phosphorus compounds compared to nitrogen-based compounds.
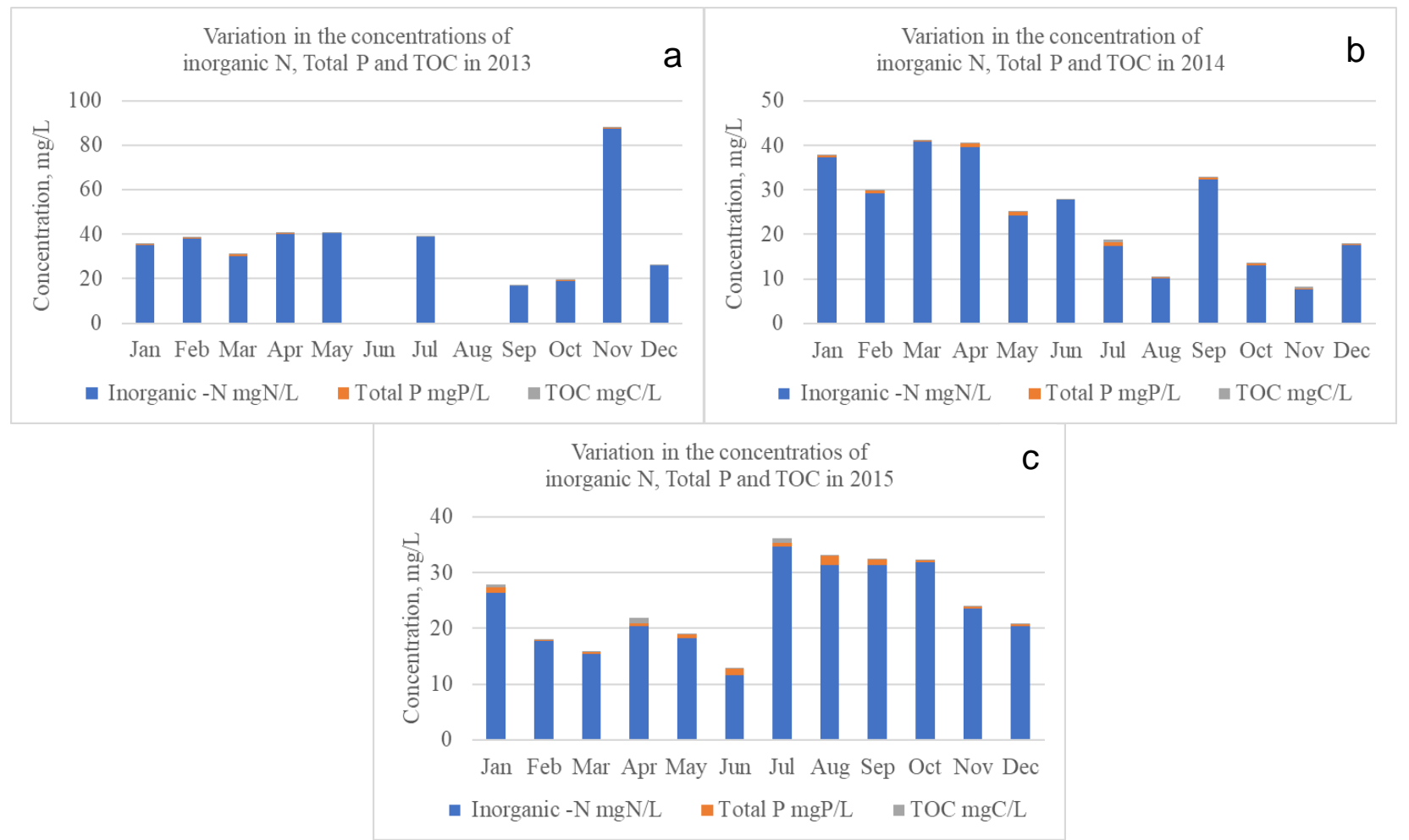

Fig. 5. Concentrations of inorganic nitrogen, total phosphorus and total organic carbon for the samples taken from S2 (a) 2013, (b) 2014, (c) 2015

Nitrate and nitrite concentrations have increased in the last century, and the clearest signal can be seen in figure 5 , in which, for all 3 years in which the concentrations of parameters of interest were evaluated, high values of inorganic nitrogen concentrations are observed.

Table 4. Stoichiometric estimates of total nitrogen, total phosphorus and total organic carbon from wastewater samples collected from S3 sampling point during 2015-2017

\begin{tabular}{c|cccccccccccc}
\hline Month & Jan & Feb & Mar & Apr & May & Jun & Jul & Aug & Sep & Oct & Nov & Dec \\
\hline C/N/2015 & - & - & - & - & - & - & 0.01 & 0.07 & 0.08 & 0.06 & 0.04 & 0.05 \\
$\mathrm{C} / \mathrm{P} / 2015$ & - & - & - & - & - & - & 0.06 & 0.55 & 0.73 & 0.60 & 0.26 & 0.37 \\
$\mathrm{~N} / \mathrm{P} / 2015$ & - & - & - & - & - & - & 6.32 & 7.65 & 8.71 & 10.6 & 6.11 & 7.45 \\
$\mathrm{C} / \mathrm{N} / 2016$ & 0.21 & 0.36 & - & 0.21 & 0.29 & 0.20 & 0.33 & 0.14 & 0.00 & 0.14 & 0.15 & 0.20 \\
$\mathrm{C} / \mathrm{P} / 2016$ & 1.64 & 0.36 & - & 0.86 & 3.84 & 14.4 & 4.39 & 6.22 & 0.09 & 1.75 & 2.38 & 3.01 \\
$\mathrm{~N} / \mathrm{P} / 2016$ & 7.81 & 11.7 & - & 4.05 & 13.0 & 73.5 & 13.3 & 43.9 & 19.5 & 12.6 & 16.1 & 15.1 \\
$\mathrm{C} / \mathrm{N} / 2017$ & 0.06 & 0.17 & 0.05 & 0.20 & 0.08 & 0.02 & 0.03 & 0.02 & 0.25 & 0.11 & 0.02 & 0.03 \\
$\mathrm{C} / \mathrm{P} / 2017$ & 2.50 & 2.34 & 0.97 & 3.75 & 1.34 & 0.15 & 0.15 & 0.25 & 4.85 & 9.60 & 0.16 & 0.20 \\
$\mathrm{~N} / \mathrm{P} / 2017$ & 45.2 & 13.9 & 19.1 & 18.8 & 17.8 & 6.44 & 4.60 & 11.7 & 19.3 & 88.6 & 7.64 & 8.10 \\
\hline
\end{tabular}

In table 4 the values of the ratios $(\mathrm{C} / \mathrm{N}, \mathrm{C} / \mathrm{P}, \mathrm{N} / \mathrm{P})$ varied from one season to another as follows: there is an increase in the value of the $\mathrm{C} / \mathrm{N}$ ratio in the studied period, $\mathrm{C} / \mathrm{N}$ in the winter season < $\mathrm{C} / \mathrm{N}$ in the spring season $<\mathrm{C} / \mathrm{N}$ in the summer season. The values of the $\mathrm{C} / \mathrm{P}$ ratio in the winter season $<\mathrm{C} / \mathrm{N}$ in the spring season $<\mathrm{C} / \mathrm{N}$ in the autumn season $\angle \mathrm{C} / \mathrm{N}$ in the summer season. The 
values of the N/P ratio in the autumn season $>\mathrm{N} / \mathrm{P}$ in the summer season $>\mathrm{N} / \mathrm{P}$ in the winter season $>\mathrm{N} / \mathrm{P}$ in the spring season.

In the results described in table 4 it can be seen that the $\mathrm{C} / \mathrm{N}$ ratio values are subunit and suggest that in the analyzed wastewater samples, the existence of nitrogen compounds was significant and organic carbon was found in minimal quantities. The values of the $\mathrm{C} / \mathrm{P}$ ratios situated in the range (0.06 - 9.60) indicates that the values of phosphorus compounds are higher than the values of compounds with organic carbon content. For the N/P ratio with values in the range $(4.05 \div 45.2)$ we can say that the analyzed samples had a high total nitrogen content.
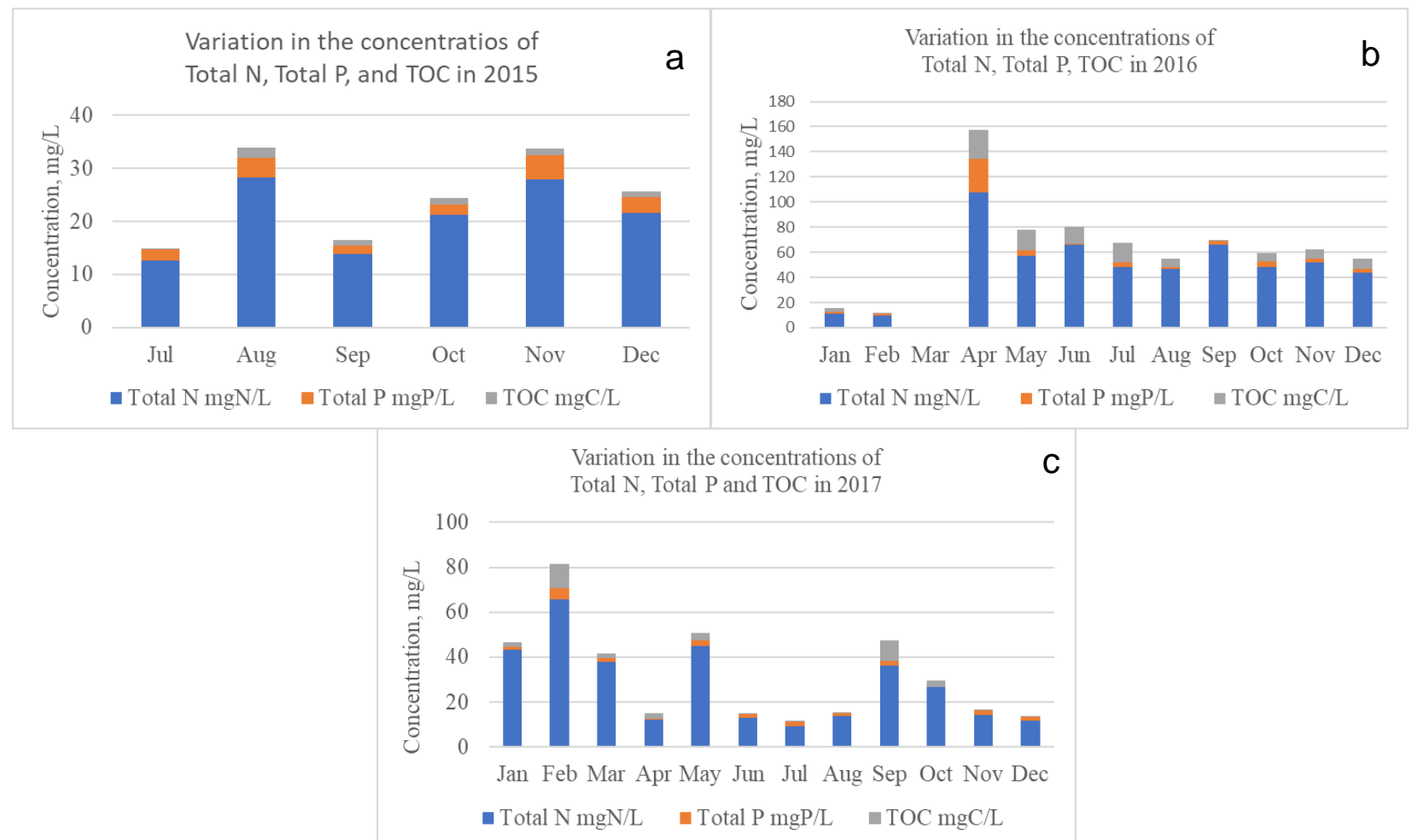

Fig. 6. Concentrations of total nitrogen, total phosphorus and total organic carbon for the samples taken from S3 (a) 2015, (b) 2016, (c) 2017

The increased values of total nitrogen provide us with information about the concentrations of organic nitrogen and inorganic nitrogen existing in the wastewater samples taken and analyzed (Figure 6). In the evaluated period of time (2015-2017), the total nitrogen had concentration values as follows: in 2015, the maximum total nitrogen value was $28.2 \mathrm{mg} / \mathrm{L}$ in August, in 2016 the total nitrogen had a maximum in April, $107.2 \mathrm{mg} / \mathrm{L}$, and in 2017, in February, total nitrogen had a maximum of $65.8 \mathrm{mg} / \mathrm{L}$.

\section{CONCLUSIONS}

In this paper, stoichiometric ratios $(\mathrm{C} / \mathrm{N}, \mathrm{C} / \mathrm{P}, \mathrm{N} / \mathrm{P})$ were used to evaluate the variation of the concentrations of inorganic nitrogen, total nitrogen, total phosphorus, total organic carbon. Similarities were observed between all three sampling sites. The ratios between $\mathrm{C} / \mathrm{N}$ proved to be sub unitary, while $\mathrm{C} / \mathrm{P}$ and N/P ratio values were supra unitary. Thus, the wastewater samples were loaded with higher content of nitrogen compounds compared to organic carbon and lower amount of phosphorous compounds compared to organic carbon and nitrogen compounds.

The presence of higher concentration values of nitrogen could be generated by both the presence of ammonia, nitrate, nitrite and organic compounds with nitrogen in the wastewater samples analyzed from S1 and S3, while higher concentration of phosphorous compounds in wastewater samples collected from S2 sampling point could be due to the presence of personal care products that contains many active substances and excipients phosphorous based. 


\section{REFERENCES}

[1] MOHSENPOUR, S.F., HENNIGE, S., WILlOUGHBY, N., ADELOYE, A., GUTIERREZ, T., Sci. Total Environ., 752, 2021, p. 142168, https://doi.org/10.1016/j.scitotenv.2020.142168.

[2] WAN, J., GU, J., ZHAO, Q., LIU, Y., Sci. Rep., 6, no. 1, 2016, 25054, https://doi.org/10.1038/srep25054.

[3] NGHIEM, L.D., KOCH, K., BOLZONELlA, D., DREWES, J.E., Renew. Sust. Energ. Rev., 72, no. 11, 2017, p. 354.

[4] PENG, Y.Y., GAO, F., YANG, H.L., WU, H.W.J., LI, C., LU, M.M., YANG, Z.Y., Sci. Total Environ., 725, 2020, p.11, https://doi.org/10.1016/j.scitotenv.2020.138524.

[5] GODOS, I., GONZALEZ, C. , BECARES, E. , GARCIA-ENCINA, P.A., MUNOZ, R., Environ. Biotechnol., 82, 2009, p. 187.

[6] SU, Y., MENNERICH, A., URBAN, B., Water Res., 45, no.11, 2011, p. 3351.

[7] ZOU, S., XU, W., ZHANG, R., TANG, J., CHEN, Y., ZHANG, G., Environ. Pollut. 159, 2011, p. 2913.

[8] SUN, M., CHANG, Z., VAN DEN BRINK, P.J., LI, J., ZHAO, F., RICO, A., Environ. Sci. Pollut. Res., 23, 2016, p. 15689.

[9] JIMENEZ, J., VEDRENNE, F., DENIS C., MOTTET, A., DELERIS, S., STEYER J.-P., CACHO RIVERO, J. A., Water Res., 47, no. 5, 2013, p. 1751.

[10] KIM, M., NAKHLA, G., KELEMAN, M., J. Environ. Manage., 237, 2019, p. 344.

[11] HABEEB, O.A., KANTHASAMY, R., GOMAA, A.M.A., SETHUPATHI, S., MOHD YUNUS, R.B., Rev. Chem. Eng. 34, no. 6, 2017, p.837, https://doi.org/10.1515/revce-2017-0004.

[12] KOLPIN, D.W., FURLONG, E.T., MEYER, M.T., THURMAN, E.M., ZAUGG, S.D., BARBER, L., BUXTON, H.T., Environ. Sci. Technol., 36, no.6, 2002, p.1202, doi: https://doi.org/10.1021/es011055j.

[13] PRONK, M., ABBAS, B., KLEEREBEZEM, R., LOOSDRECHT, M.C.M., Microb Biotechnol., 8, no.5, 2015, p. 853, 10.1111/1751-7915.12292.

[14] LIU, Y.Q., LAN, G.H., ZENG, P., Appl. Microbiol. Biotechnol. 99, no.19, 2015, p. 8225, https://doi.org/10.1016/j.biortech.2016.06.111.

[15] WAGNER, J., GUIMARAES, L.B., AKABOCI, T.R.V., COSTA, R.H.R. Water Sci. Technol., 71, no. 7, 2015, p. 1040, https://doi.org/10.2166/wst.2015.064.

[16] WANG, J., WANG, X., ZHAO, Z., LI, J., Appl. Microbiol. Biotechnol. no.79, 2008, p. 679.

[17] WINKLER, M.K.H., KLEEREBEZEM, R., van LOOSDRECHT, M., Water Res. 46, 2012, p. 136, https://doi.org/10.1016/j.watres.2011.10.034.

[18] LIU, X., DONG, C., Syst. Eng Proc. no. 1, 2011, p. 99.

[19] DIAZ, J.M., BJORKMAN, K.M., HALEY, S.T., INGALL, E.D., KARL, D.M., LONGO, A.F., DYHRMAN, S.T., Limnol. Oceanogr., 61, no. 1, 2016, p. 227.

[20] DYHRMAN, S.T., The Physiology of Microalgae, Springer International Publishing, Cham 2016, p. 155.

[21] SOLOVCHENKO, A.E., ISMAGUlOVA, T.T., LUKYANOV, A.A., VASILIEVA, S.G., KONYUKHOV, I.V., POGOSYAN, S.I., LOBAKOVA, E.S., GORELOVA, O.A., J. Appl. Phycol., 31, no.5, 2019, p. 2755.

[22] MANISALI, A.Y. SUNOL, A.K., PHILIPPIDIS, G.P., Algal Res., 41, no. 5, 2019, 101514, https://doi.org/10.1016/j.algal.2019.101514.

[23] POWELL, N., SHILTON, A., CHISTI, Y., PRATT, S. Water Res., 43, no.17, 2009, p. 4207.

[24] POWELL, N., SHILTON, A., PRATT, S., CHISTI, Y., Water Sci. Technol., 63, no. 4, 2011, p. 704.

[25] WANG, X.X., ZHANG, T.Y., DAO, G.H., XU, Z.B., WU, Y.H., HU, H.Y. Water Res., 186, 2020, https://doi.org/10.1016/j.watres.2020.116333.

[26] NTPA 001/2005 "Normative regarding the establishment of the loading limits with pollutants of industrial and urban wastewater for discharge in natural receptors" according to HG 352/2005.

[27] ISO 7150-1:1984: Water quality. Determination of ammonium, Part 1: Manual spectrometric method. 
[28] EN 12260:2003: Water quality. Determination of nitrogen: Determination of bound nitrogen $(\mathrm{TNb})$, following oxidation to nitrogen oxides.

[29] ISO 7890-3:1988: Water quality. Determination of nitrate.

[30] EN 26777:1993: Water quality. Determination of nitrite, Molecular absorption spectrometric method.

[31] ISO 6878:2004: Water quality. Determination of phosphorus: Ammonium molybdate spectrometric method.

Citation: Pirvu, F., Paun, I., Niculescu, M., Iancu, V.I., Pascu, L.F., Chiriac, F.L., Stoichiometry of carbon, nitrogen and phosphorus in wastewater from Romania, Rom. J. Ecol. Environ. Chem., 2021, 3, no.2, pp. 120129.

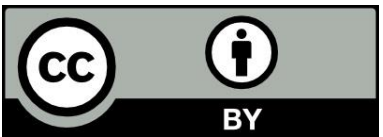

(C) 2021 by the authors. This article is an open access article distributed under the terms and conditions of the Creative Commons Attribution (CC BY) license (http://creativecommons.Org/licenses/by/4.0/). 